\title{
Inactivation of Caliciviruses
}

\author{
Erwin Duizer, ${ }^{*}$ Paul Bijkerk, Barry Rockx, Astrid de Groot, Fleur Twisk, and Marion Koopmans \\ Diagnostic Laboratory for Infectious Diseases and Perinatal Screening, National Institute for \\ Public Health and the Environment, 3720 BA Bilthoven, The Netherlands
}

Received 8 December 2003/Accepted 5 May 2004

\begin{abstract}
The viruses most commonly associated with food- and waterborne outbreaks of gastroenteritis are the noroviruses. The lack of a culture method for noroviruses warrants the use of cultivable model viruses to gain more insight on their transmission routes and inactivation methods. We studied the inactivation of the reported enteric canine calicivirus no. $48(\mathrm{CaCV})$ and the respiratory feline calicivirus $\mathrm{F9}(\mathrm{FeCV})$ and correlated inactivation to reduction in PCR units of $\mathrm{FeCV}, \mathrm{CaCV}$, and a norovirus. Inactivation of suspended viruses was temperature and time dependent in the range from 0 to $100^{\circ} \mathrm{C}$. UV-B radiation from 0 to 150 $\mathrm{mJ} / \mathrm{cm}^{2}$ caused dose-dependent inactivation, with a $3 D\left(D=1 \log _{10}\right)$ reduction in infectivity at $34 \mathrm{~mJ} / \mathrm{cm}^{2}$ for both viruses. Inactivation by $70 \%$ ethanol was inefficient, with only $3 \mathrm{D}$ reduction after $30 \mathrm{~min}$. Sodium hypochlorite solutions were only effective at $>300 \mathrm{ppm}$. FeCV showed a higher stability at $\mathrm{pH}<3$ and $\mathrm{pH}>7$ than CaCV. For all treatments, detection of viral RNA underestimated the reduction in viral infectivity. Norovirus was never more sensitive than the animal caliciviruses and profoundly more resistant to low and high pH. Overall, both animal viruses showed similar inactivation profiles when exposed to heat or UV-B radiation or when incubated in ethanol or hypochlorite. The low stability of CaCV at low pH suggests that this is not a typical enteric (calici-) virus. The incomplete inactivation by ethanol and the high hypochlorite concentration needed for sufficient virus inactivation point to a concern for decontamination of fomites and surfaces contaminated with noroviruses and virus-safe water.
\end{abstract}

The viruses most commonly associated with outbreaks of gastroenteritis are the noroviruses (formerly know as small round structured viruses and Norwalk-like viruses). In the Western world, these highly infectious viruses reportedly cause 68 to $80 \%$ of gastroenteritis outbreaks $(16,28)$, but estimates as high as $90 \%$ for outbreaks have been reported (19). The relative contribution of the noroviruses to food- and waterborne outbreaks is estimated to vary between 5 and $15 \%$ (16, 28). The resistance of noroviruses to culturing (14) has hampered the development of reliable methods for their detection and viability testing. Therefore, knowledge of efficient inactivation methods and effective intervention in transmission pathways is limited and based on studies with model viruses $(13,22$, 39, 40; reviewed in reference 23).

The noroviruses are members of the family Caliciviridae. Caliciviruses are important veterinary and human pathogens and cause a wide range of symptoms by infecting a variety of organs $(8,9)$. The human caliciviruses, i.e., the noroviruses and the sapoviruses, are all enterotropic and cause gastrointestinal illness $(27,37)$. Most caliciviruses isolated from domestic cats (feline calicivirus [FeCV]) cause severe respiratory illness and limping disease, but some strains were etiologically associated with diarrhea $(20,30)$. Calicivirus-related disease in dogs is less common, but some canine calicivirus $(\mathrm{CaCV})$ strains were isolated from dogs with diarrhea and vesicular genital lesions (31, 32). It is plausible to assume that viruses that use the same transmission route and replication site possess comparable stabilities. The (food-borne) enteric viruses survive the harsh con-

\footnotetext{
* Corresponding author. Mailing address: National Institute for Public Health and the Environment (RIVM), Diagnostic Laboratory for Infectious Diseases and Perinatal Screening (LIS), P.O. Box 1, 3720 BA Bilthoven, The Netherlands. Phone: 31030274 4142. Fax: 31 30274 4418. E-mail: Erwin.Duizer@rivm.nl.
}

ditions in the gastrointestinal tract, such as low $\mathrm{pH}$ and high bile concentrations $(10,30)$, and in general, enteric viruses are considered more resistant to environmental factors and disinfection methods than respiratory viruses. Therefore, in these studies, we determined the inactivation profiles of the widely studied norovirus surrogate FeCV-F9 (respiratory) vaccine strain and the antigenically unrelated reported enteric $\mathrm{CaCV}$ no. 48 strain.

In one series of experiments, we applied a variety of physical and chemical conditions to assess the stability of three different caliciviruses (FeCV, $\mathrm{CaCV}$, and norovirus) by three different methods, culture and conventional and quantitative reverse transcription (RT)-PCR. The viruses in suspension were stored at $4^{\circ} \mathrm{C}$ and room temperature to determine environmental survival. They were exposed to heat and multiple cycles of freeze-thawing to obtain data that may be used to assess the survival of caliciviruses (i.e., noroviruses) during food processing and storage. Resistance to high and low $\mathrm{pH}$ was studied to assess the likelihood of stomach passage for the enteric viruses. Viruses were exposed to UV-B radiation as a factor in environmental survival and to $70 \%$ ethanol and sodium hypochlorite dilutions ( 0 to $6,000 \mathrm{ppm}$ ) to determine effective inactivation methods for cleaning practices. The methods found to be effective for complete inactivation of $\mathrm{FeCV}$ and $\mathrm{CaCV}$ were applied to a norovirus (genogroup II.4)-positive stool sample suspension, and the presence of viral RNA was determined by conventional RT-PCR and a newly developed quantitative real time RT-PCR.

\section{MATERIALS AND METHODS}

Viruses and cells. Crandell-Reese feline kidney (CRFK) cells and MadinDarby canine kidney (MDCK) cells were cultured in Dulbecco's modified Eagle's medium (DMEM) supplemented with $10 \%$ (vol/vol) heat-inactivated fetal calf serum, gentamicin $(50 \mu \mathrm{g} / \mathrm{ml})$, and $1 \%$ (vol/vol) nonessential amino acids. 
The maintenance medium for virus propagation was identical but with 0 to $2 \%$ (vol/vol) fetal calf serum. FeCV strain F9 (kindly provided by H. Egberink, Utrecht University, The Netherlands) was propagated in monolayers of CRFK cells. CaCV strain no. 48 (kindly provided by F. Roerink, Kyoritsu Shoji Corporation, Japan) was propagated in MDCK cells. Cell and virus cultures were done at $37^{\circ} \mathrm{C}$ in an atmosphere of $5 \% \mathrm{CO}_{2}$ and $90 \%$ relative humidity.

Virus stocks used in the inactivation experiments were obtained by inoculation of young cells (24 to $48 \mathrm{~h}$ after seeding) at a multiplicity of infection of 0.1 . The suspensions were harvested after $24 \mathrm{~h}$ by one cycle of freezing and thawing and clarified by centrifugation $\left(10 \mathrm{~min}, 1,800 \times g, 4^{\circ} \mathrm{C}\right)$. The clarified stocks contained $2 \times 10^{6}$ to $9 \times 10^{6} 50 \%$ tissue culture infectious doses $\left(\mathrm{TCID}_{50}\right) / \mathrm{ml}$ and 30 to 40 $\mu \mathrm{g}$ of protein $/ \mathrm{ml}$ and were stored at $-70^{\circ} \mathrm{C}$. Virus stocks for inactivation experiments were standardized to contain $2 \times 10^{5}$ to $1 \times 10^{6} \mathrm{TCID}_{50} / \mathrm{ml}$ and 3 to $4 \mu \mathrm{g}$ of protein $/ \mathrm{ml}$ in cell culture medium without fetal calf serum or in sterilized demineralized water (in the UV irradiation experiment).

The norovirus genogroup II.4 strain (Hu/NV/DenHaag22/2001/NL) suspension was prepared from a stool sample from a patient with acute gastroenteritis that tested positive for norovirus by RT-PCR (41). A $10 \%$ (vol/vol) stool suspension was prepared in DMEM with gentamicin $(100 \mu \mathrm{g} / \mathrm{ml})$. This suspension was centrifuged at $2,000 \times g$ for $30 \mathrm{~min}$, subsequently extracted with $10 \%$ $(\mathrm{vol} / \mathrm{vol})$ chloroform, centrifuged again at 3,000 $\times \mathrm{g}$ for $10 \mathrm{~min}$, dispensed, and stored at $4^{\circ} \mathrm{C}$.

Inactivation experiments. After exposure to UV-B radiation, chlorine, or ethanol, samples were analyzed immediately. Samples collected in the thermal inactivation and $\mathrm{pH}$ stability series were frozen and stored at $-20^{\circ} \mathrm{C}$ prior to analysis. The titers of infectious virus were determined as $\mathrm{TCID}_{50}$ in cell culture (in the 96-well format).

Thermal inactivation. Virus stocks were dispensed in $250-\mu l$ fractions and kept at $4,20,27,37,56,63,71.3$, and $100^{\circ} \mathrm{C}$ for time periods varying from weeks $\left(4^{\circ} \mathrm{C}\right)$ to seconds $\left(71.3\right.$ and $\left.100^{\circ} \mathrm{C}\right)$. Samples were collected and stored at $-20^{\circ} \mathrm{C}$ until titration. Effects of freeze-thawing cycles (up to five cycles) were studied by freezing dispensed samples $(0.5 \mathrm{ml})$ by transfer from room temperature to $-70^{\circ} \mathrm{C}$ and subsequent thawing in a water bath at room temperature.

UV irradiation. Viral suspensions $(250 \mu \mathrm{l})$ were exposed to UV-B radiation in 24 wells (area, $1 \mathrm{~cm}^{2}$ ) on melting ice (to prevent heating effects and evaporation) for 0 to $30 \mathrm{~min}$. The UV source (STX-35 M; UVItec, Cambridge, United Kingdom) emitted UV-B (280 to $320 \mathrm{~nm}$ ) at $0.43 \mathrm{~mJ} \mathrm{~cm}^{-2} \mathrm{~s}^{-1}$, measured at the sample level with the Optronic OL-752-PMT spectroradiometer (Orlando) Samples were titrated immediately after exposure.

pH stability. To test stability at $\mathrm{pH} 3$, virus suspensions were incubated in citric acid buffer at $\mathrm{pH} 3$ for $30 \mathrm{~min}$ at $37^{\circ} \mathrm{C}$. Acidic $\mathrm{pH}$ was neutralized through dilution with phosphate buffer, $\mathrm{pH}$ 8.1. Additionally, $5 \mathrm{M} \mathrm{HCl}$ and $1 \mathrm{M} \mathrm{NaOH}$ stock solutions were used to make virus suspensions in DMEM covering the $\mathrm{pH}$ range from 1 to 14 . The suspensions were incubated at $37^{\circ} \mathrm{C}$ for $30 \mathrm{~min}$. Low and high $\mathrm{pHs}$ were neutralized by 10 -fold dilution in DMEM, and samples were titrated immediately.

Inactivation by ethanol. Virus suspensions were diluted in $96 \%$ (vol/vol) ethanol to yield a final concentration of $70 \%$ (vol/ $/ \mathrm{vol})$ ethanol. Virus was exposed to $70 \%$ (vol/vol) ethanol for up to $1 \mathrm{~h}$ at room temperature $\left(18\right.$ to $22^{\circ} \mathrm{C}$ ). After the exposure time, the suspensions were diluted 10 -fold to lower the ethanol concentration, hence reducing cytotoxicity, and titrated immediately.

Inactivation by chlorine. Sodium hypochlorite solution (6 to $14 \%$ active chlorine; Merck, Darmstadt, Germany) was diluted to $1 \%$ in demineralized water to prepare suspensions containing 0 to $300 \mathrm{ppm}$ free chlorine. The free chlorine concentration in the stock was determined with the $N, N$,-diethyl- $p$-phenylenediamine method and a chlorine test kit according to the manufacturer's instructions (Hach). The higher hypochlorite concentrations were prepared by adding the undiluted sodium hypochlorite solution to the virus stock solutions. After exposures of 10 and $30 \mathrm{~min}$ at room temperature, the free chlorine was neutralized by $1 \%(\mathrm{wt} / \mathrm{vol}) \mathrm{Na}_{2} \mathrm{~S}_{2} \mathrm{O}_{3}$. No decrease in virus titer was detected when a virus suspension was added to a mixture of sodium hypochlorite solution and $\mathrm{Na}_{2} \mathrm{~S}_{2} \mathrm{O}_{3}$.

RT-PCR. Viral RNA was extracted by the Boom method as described before $(3,41)$. Reverse transcription of the extracted RNA was done for $60 \mathrm{~min}$ at $42^{\circ} \mathrm{C}$ after annealing with an in-house $\mathrm{CaCV}$ YGDD primer, FeCV-YGDD primer, or the JV13I primer for $\mathrm{CaCV}, \mathrm{FeCV}$, and norovirus (Table 1), respectively. RT primers were used at $50 \mathrm{pmol}$ in $15 \mu \mathrm{l}$ of $10 \mathrm{mM}$ Tris- $\mathrm{HCl}(\mathrm{pH} 8.3)-50 \mathrm{mM}$ $\mathrm{KCl}-3 \mathrm{mM} \mathrm{MgCl}-1 \mathrm{mM}$ deoxynucleoside triphosphates-40 U of RNAguard per ml-5 U of avian myeloblastosis virus reverse transcriptase (Promega, Leiden, The Netherlands); $5 \mu \mathrm{l}$ of the mix was added to $45 \mu \mathrm{l}$ of a PCR mix containing $10 \mathrm{mM}$ Tris- $\mathrm{HCl}$ (pH 9.2), $75 \mathrm{mM} \mathrm{KCl}, 1.2 \mathrm{mM} \mathrm{MgCl}_{2}$ (final concentration, 1.5 $\mathrm{mM}$ ), $0.2 \mathrm{mM}$ deoxynucleoside triphosphates, $2.5 \mathrm{U}$ of AmpliTaq, and $0.3 \mathrm{mM}$ $\mathrm{BR} 1$ for $\mathrm{CaCV}$ and $\mathrm{FeCV}$ or JV12Y for norovirus. Samples were denatured for

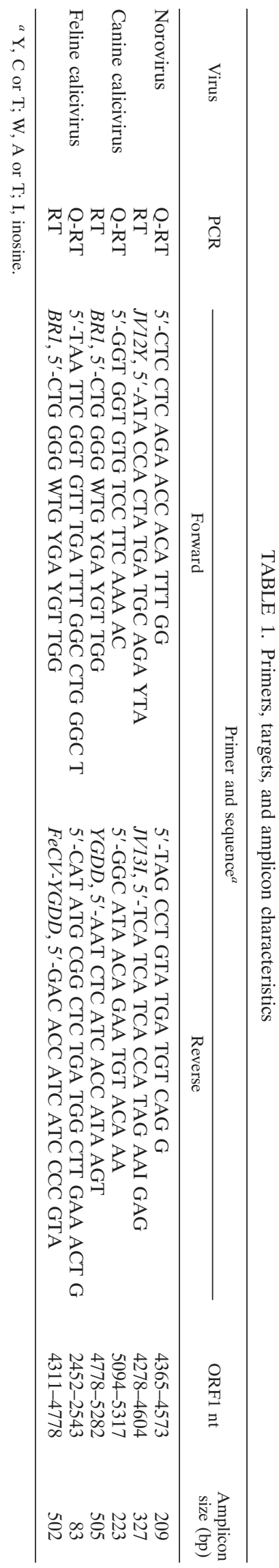




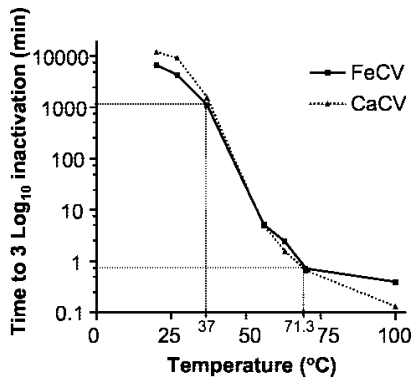

FIG. 1. Times required at different temperatures to achieve a 3 $\log _{10}$ reduction in viable virus titer $\left(\mathrm{TCID}_{50}\right)$ in DMEM (3 to $4 \mu \mathrm{g}$ of $\operatorname{protein} / \mathrm{ml})$.

$3 \mathrm{~min}$ at $94^{\circ} \mathrm{C}$ and subjected to 40 cycles at $94^{\circ} \mathrm{C}$ for $1 \mathrm{~min}, 37^{\circ} \mathrm{C}$ for $1.5 \mathrm{~min}$, and $74^{\circ} \mathrm{C}$ for $1 \mathrm{~min}$. PCR products were analyzed by agarose gel electrophoresis.

Real-time RT-PCR. Viral RNA was extracted by the Boom method as described before $(3,41)$. Reverse transcription was performed at $42^{\circ} \mathrm{C}$ for $60 \mathrm{~min}$ with $1 \mu \mathrm{l}$ of reverse primer $(50 \mathrm{pmol} / \mu \mathrm{l}), 2.5 \mu \mathrm{l}$ of genomic RNA, $0.5 \mu \mathrm{l}$ of avian myeloblastosis virus reverse transcriptase $(10 \mathrm{U} / \mu \mathrm{l}), 1.5 \mu \mathrm{l}$ of $10 \times \mathrm{PCR}$ buffer (Promega), $1.8 \mu \mathrm{l}$ of $\mathrm{MgCl}_{2}(25 \mathrm{mM}), 1.5 \mu \mathrm{l}$ of deoxynucleoside triphosphates (10 $\mathrm{mM}$; Roche), and $6.2 \mu \mathrm{l}$ of water; $2 \mu \mathrm{l}$ of the cDNA was used in a Lightcycler (Roche) PCR with forward primer (6 pmol), $2 \mu \mathrm{l}$ of SyberGreen I (Roche), and water up to $20 \mu \mathrm{l}$. The PCR program had an initial denaturation step at $95^{\circ} \mathrm{C}$ for $30 \mathrm{~s}$, followed by 40 cycles of denaturation for $1 \mathrm{~s}$ at $95^{\circ} \mathrm{C}, 10 \mathrm{~s}$ of annealing at $42^{\circ} \mathrm{C}(\mathrm{FeCV}$ and $\mathrm{CaCV}$ ) or $46^{\circ} \mathrm{C}$ (for norovirus), and $13 \mathrm{~s}$ of elongation at $72^{\circ} \mathrm{C}$. Immediately following PCR, a melting curve was performed by raising the temperature from 65 to $95^{\circ} \mathrm{C}$ in $0.1^{\circ} \mathrm{C}$ increments. See Table 1 for primers and PCR product fragment lengths. The primers used for $\mathrm{FeCV}$ were published before (21).

\section{RESULTS}

Thermal inactivation. The inactivation of both viruses at $4{ }^{\circ} \mathrm{C}$ was $<1 D\left(D=1 \log _{10}\right.$, calculated by dividing the $\mathrm{TCID}_{50}$ of the treated sample by the $\mathrm{TCID}_{50}$ of the untreated sample) in 2 weeks (data not shown). Data for the times required to achieve $3 D$ inactivation at higher temperatures are presented in Fig. 1. Virus inactivation was found to be temperature dependent and comparable for both viruses. At $20^{\circ} \mathrm{C}$ a $3 \mathrm{D}$ reduction in infectivity occurred in 1 week. A steep decrease was found between 37 and $56^{\circ} \mathrm{C}$, where the time to $3 \mathrm{D}$ inactivation decreased from approximately $24 \mathrm{~h}$ to $8 \mathrm{~min}$. Heating to $71.3^{\circ} \mathrm{C}$ (pasteurization temperature) resulted in $3 \mathrm{D}$ inactivation in $1 \mathrm{~min}$ for both viruses. The reduction of infectivity by five cycles of freezing and thawing was $0.44 \pm 0.12 \mathrm{D}$ and $0.34 \pm 0.18 D$ for $\mathrm{CaCV}$ and FeCV, respectively $(n=4)$.

UV inactivation. The inactivation of $\mathrm{FeCV}$ and $\mathrm{CaCV}$ by UV-B radiation was dose dependent and comparable for both

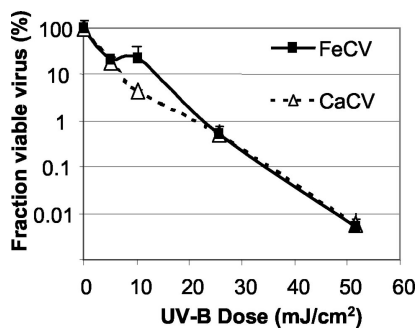

FIG. 2. Inactivation of caliciviruses in suspension by UV-B irradiation at $0^{\circ} \mathrm{C}$. The dose is presented as cumulative irradiation at $0.43 \mathrm{~mJ}$ $\mathrm{cm}^{-2} \mathrm{~s}^{-1}$ for different exposure times. Error bars indicate 1 standard deviation $(n=4)$.

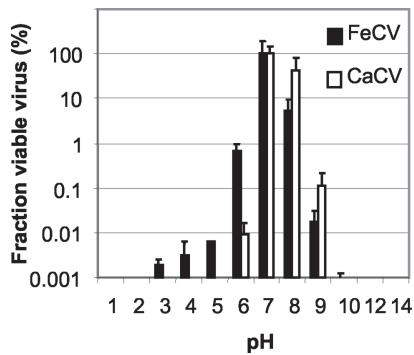

FIG. 3. Inactivation of caliciviruses in suspension incubated for 30 min at $37^{\circ} \mathrm{C}$ at different pHs. Error bars indicate 1 standard deviation $(n=4)$.

viruses (Fig. 2). In the setup we used, $2 D$ inactivation was found at 21 and $22 \mathrm{~mJ} / \mathrm{cm}^{2}$ for $\mathrm{CaCV}$ and $\mathrm{FeCV}$, respectively, and $3 D$ inactivation was found after exposure to $34 \mathrm{~mJ} / \mathrm{cm}^{2}$ for both animal caliciviruses.

pH stability. For $\mathrm{CaCV}$, more than $5 \mathrm{D}$ inactivation was found for $\mathrm{pH}$ values of 5 and lower and 10 and higher (Fig. 3). At alkaline pHs, the $\mathrm{FeCV}$ appeared less resistant than the $\mathrm{CaCV}$, with an almost $4 \mathrm{D}$ reduction at $\mathrm{pH} 9$ for $\mathrm{FeCV}$ against a $3 \mathrm{D}$ reduction for $\mathrm{CaCV}$. At acidic $\mathrm{pHs}$, the $\mathrm{FeCV}$ is more stable, and at pH 6 the infectivity of $\mathrm{FeCV}$ is reduced $2 \mathrm{D}$, while the $\mathrm{CaCV}$ infectivity is down by $4 \mathrm{D}$. More than $5 \mathrm{D}$ inactivation was found for $\mathrm{FeCV}$ only at a $\mathrm{pH}$ of 2 and lower or 10 and higher.

Inactivation by ethanol. Viral inactivation by $70 \%$ ethanol was comparable for both viruses (Fig. 4). After 8 min, less than a $2 D$ reduction in $\mathrm{TCID}_{50}$ was found, and a $3 D$ reduction was seen after $30 \mathrm{~min}$ for both viruses.

Inactivation by sodium hypochlorite. Viral inactivation by sodium hypochlorite in the virus-DMEM suspensions was ineffective ( $<1 D$ inactivation) up to concentrations of $30 \mathrm{ppm}$ free chlorine (Fig. 5). Inactivation by $300 \mathrm{ppm}$ was effective (>3 D inactivation) for $\mathrm{CaCV}$ but clearly less effective for $\mathrm{FeCV}(<2 \mathrm{D}$ inactivation). An increase in exposure time from 10 to $30 \mathrm{~min}$ did not result in a significant increase in the effectiveness of sodium hypochlorite for FeCV inactivation, but $\mathrm{CaCV}$ inactivation was increased $1 \mathrm{D}$ at $300 \mathrm{ppm}$ chlorine (data not shown). Complete inactivation $(>5 D)$ of $\mathrm{FeCV}$ and $\mathrm{CaCV}$ was found for chlorine levels of 3,000 ppm (or higher) in 10 and $30 \mathrm{~min}$ at room temperature.

Detection of viral RNA of inactivated viruses. The viral RNA contents of virus stock dilutions and completely inactivated virus suspensions were determined with conventional and real-time RT-PCR methods (Table 2). The virus suspen-

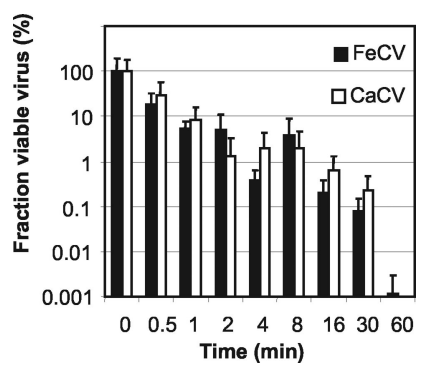

FIG. 4. Inactivation of caliciviruses in suspension at room temperature by $70 \%$ ethanol. Error bars indicate 1 standard deviation $(n=4)$. 


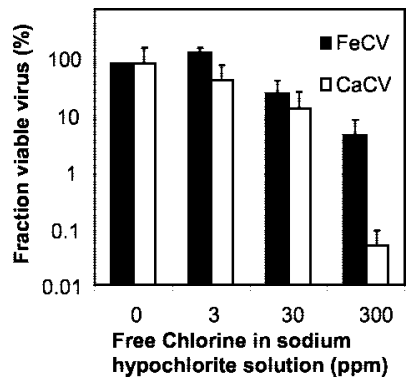

FIG. 5. Inactivation of caliciviruses by $10 \mathrm{~min}$ in suspension at room temperature with sodium hypochlorite. Error bars indicate 1 standard deviation $(n=4)$.

sions contained approximately $6 \times 10^{9}, 6 \times 10^{8}$, and $1.2 \times 10^{6}$ PCR units/ml for FeCV, CaCV, and norovirus, respectively, as determined by endpoint dilution in conventional RT-PCR. The dilution series of all three virus suspensions showed an increase in cycle threshold ( $C_{t}$ value $)$ in the real-time RT-PCR with increasing dilution and an average difference in $C_{t}$ value $\left(\mathrm{d} C_{t}\right)$ of 4.1 cycles per 10 -fold dilution for $\mathrm{FeCV}$ and $\mathrm{CaCV}$ and 3.8 for norovirus (Fig. 6).

A less than $1 D$ reduction in PCR units by exposure to $37^{\circ} \mathrm{C}$ for up to $168 \mathrm{~h}$ was determined for all three caliciviruses, while for the $\mathrm{FeCV}$ and $\mathrm{CaCV}$ the infectivity was reduced more than $5 D$ (Table 2). Boiling for 1 min resulted in a less than $1 D$ reduction in RNA content for $\mathrm{FeCV}$ and norovirus, while the reduction of $\mathrm{CaCV}$ RNA was slightly higher. After $3 \mathrm{~min}$ at $100^{\circ} \mathrm{C}$, the RNA reduction was considerable for all three viruses, and again the effect on CaCV RNA content was higher than the effect on FeCV RNA. Complete destruction of the infectivity of $\mathrm{CaCV}$ and $\mathrm{FeCV}$ by UV irradiation was concomitant with minor reductions in PCR-detectable RNA units for the two animal viruses and the norovirus. For hypochlorite

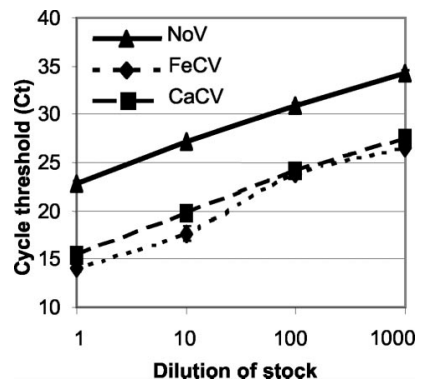

FIG. 6. $C_{t}$ values for calicivirus and norovirus (NoV) RNA in realtime PCR. RNA was extracted from the stock and diluted before the reverse transcription step. Each data point represents the average $C_{t} \pm$ 1 standard deviation (two experiments, $n=2$ ).

treatment, the elimination of infectivity was concomitant with substantial reductions in detectable RNA, with higher reductions at the higher hypochlorite concentration. Again, the reductions of $\mathrm{CaCV}$ RNA contents were found to be higher than the reductions found for FeCV RNA. Exposure to $\mathrm{pH} 2$ resulted in largely decreased RNA contents of both animal caliciviruses, as determined with both PCR protocols. In contrast, no reduction of RNA content for norovirus could be detected.

\section{DISCUSSION}

In order to increase insight into transmission routes and methods available to inactivate human enteric noroviruses, we studied the inactivation of the two animal caliciviruses $\mathrm{FeCV}$ and $\mathrm{CaCV}$. The respiratory $\mathrm{FeCV}$ has been used as a model for norovirus in inactivation studies before $(13,30,33,34,39,40)$, but little is known about the stability of $\mathrm{CaCV}$. We found that both animal caliciviruses showed long-term survival at temperatures of up to $20^{\circ} \mathrm{C}$ when incubated in suspension. The $3 \mathrm{D}$

TABLE 2. RT-PCR detection of calicivirus RNA after infectivity-abolishing treatments ${ }^{a}$

\begin{tabular}{|c|c|c|c|c|c|c|}
\hline \multirow{2}{*}{$\begin{array}{l}\text { Treatment leading to } \\
\text { complete inactivation }\end{array}$} & \multicolumn{2}{|c|}{$\mathrm{FeCV}$} & \multicolumn{2}{|c|}{$\mathrm{CaCV}$} & \multicolumn{2}{|c|}{ Norovirus } \\
\hline & $\begin{array}{l}\text { RT-PCR test } \\
\text { result }^{b}\end{array}$ & $\begin{array}{l}\text { Q-RT-PCR } \\
d C_{t}^{c}\end{array}$ & $\begin{array}{l}\text { RT-PCR test } \\
\text { result }\end{array}$ & $\begin{array}{l}\text { Q-RT-PCR } \\
d C_{t}\end{array}$ & $\begin{array}{l}\text { RT-PCR test } \\
\text { result }\end{array}$ & $\begin{array}{c}\text { Q-RT-PCR } \\
d C_{t}\end{array}$ \\
\hline $37^{\circ} \mathrm{C}, 120 \mathrm{~h}$ & ++ & 0.4 & ++ & 3.8 & ++ & 2.8 \\
\hline $37^{\circ} \mathrm{C}, 168 \mathrm{~h}$ & ++ & 0.8 & ++ & 3.3 & ++ & 4.5 \\
\hline $100^{\circ} \mathrm{C}, 1 \mathrm{~min}$ & ++ & 0.9 & ++ & 5.2 & ++ & 1.9 \\
\hline $100^{\circ} \mathrm{C}, 3 \mathrm{~min}$ & ++ & 7.8 & ++ & 12.1 & ++ & $>7.5$ \\
\hline $206 \mathrm{~mJ} / \mathrm{cm}^{2}, 0^{\circ} \mathrm{C}$ & +++ & -0.1 & ++ & 3.6 & ++ & 3.0 \\
\hline \multicolumn{7}{|l|}{$\mathrm{pH}$} \\
\hline $2,30 \mathrm{~min}, 37^{\circ} \mathrm{C}$ & --- & 6.4 & --- & 11.0 & ++ & 0.2 \\
\hline $3,30 \mathrm{~min}, 37^{\circ} \mathrm{C}$ & $+++^{e}$ & 5.6 & +-- & 5.9 & ++ & -0.3 \\
\hline $10,30 \mathrm{~min}, 37^{\circ} \mathrm{C}$ & $+++^{e}$ & 3.5 & +-+ & 7.7 & ++ & 1.6 \\
\hline $12,30 \mathrm{~min}, 37^{\circ} \mathrm{C}$ & --- & 11.3 & --- & 17.3 & ++ & 7.4 \\
\hline \multicolumn{7}{|l|}{ Hypochlorite } \\
\hline
\end{tabular}

${ }^{a}$ Infectivity-abolishing treatments gave a reduction of $>5 \log _{10}$ in $\mathrm{TCID}_{50}$ for $\mathrm{FeCV}$ and $\mathrm{CaCV}$.

${ }^{b}$ One symbol per test. +, viral RNA detected; -, viral RNA not detected.

${ }^{c} d C_{t}$, average delay in cycle threshold $\left(C_{t}\right)$ (two experiments, $\left.n=2\right)$. Q, quantitative.

${ }^{d} \mathrm{RT}$, room temperature.

${ }^{e}$ Inactivation of FeCV not complete. 
inactivation in a week that we found for FeCV F9 was less than the approximately $5 \mathrm{D}$ inactivation reported by Doultree et al. (13) at this temperature, while Allwood et al. (1) reported only a $1 \mathrm{D}$ reduction in a week at $25^{\circ} \mathrm{C}$. Another report showed survival (less than a $1 D$ reduction in infectivity) of other $\mathrm{FeCV}$ strains in marine water in 1 month at low temperatures $\left(4^{\circ} \mathrm{C}\right)$, and even at $20^{\circ} \mathrm{C}$ a $1 \mathrm{D}$ reduction took 25 days (22). Even though notable differences in time to $1 \mathrm{D}$ inactivation at room temperature have been reported, overall, both viruses showed long-term survival in suspension at environmental temperatures, indicating that transmission by a route involving, for example, drinking or surface water, moisture fomites, or workplace surfaces is possible. Indeed, norovirus-related outbreaks have been shown to be caused by contaminated drinking water in countries such as Finland, Sweden, and the United States (5, $24,35)$ and environmental contamination in settings such as hotels $(4,7)$, a rehabilitation center (25), and a concert hall (15).

Heat inactivation was highly comparable for both viruses at temperatures ranging from 37 to $100^{\circ} \mathrm{C}$. The slope of the temperature inactivation curve becomes less steep at temperatures exceeding $56^{\circ} \mathrm{C}$, meaning that small increases in temperature do not lead to significant decreases in time to $3 \mathrm{D}$ reduction of infectivity. This indicates that better inactivation of viruses may be expected from regular batch pasteurization $\left(63^{\circ} \mathrm{C}\right.$ for 30 min) or classical pasteurization $\left(70^{\circ} \mathrm{C}\right.$ for $\left.2 \mathrm{~min}\right)$ than from high-temperature, short-time pasteurization $\left(72^{\circ} \mathrm{C}\right.$ for $\left.15 \mathrm{~s}\right)$. Moreover, our results suggest that high-temperature, shorttime pasteurization would accomplish $<1 D$ inactivation of caliciviruses, indicating that this will not be the preferred method to make foods or drinks virus safe.

The data that we show on thermal inactivation of FeCV in aqueous solution are comparable to the data from Lee and Gillespie (26) and Doultree et al. (13). Remarkably, Slomka and Appleton (39) reported a comparable $3 \mathrm{D}$ inactivation in 0.5 to 1 min of $\mathrm{FeCV}$ in contaminated cockles at $80^{\circ} \mathrm{C}$, indicating that FeCV, unlike hepatitis A virus $(2,29)$, is not significantly stabilized by factors such as fat and high protein content.

To the best of our knowledge, this is the first study reporting calicivirus inactivation by UV-B (280 to $320 \mathrm{~nm}$ ) radiation. Inactivation rates of $\mathrm{FeCV}$ by $253.7-\mathrm{nm}$ radiation was reported to be highly variable, ranging from 21 to $26(40)$ and $12 \mathrm{~mJ} / \mathrm{cm}^{2}$ (11) for $3 D$ reduction in infectivity to $48 \mathrm{~mJ} / \mathrm{cm}^{2}$ for only $1 D$ inactivation (34). The UV-B dose we found to be effective in reducing $\mathrm{FeCV}$ infectivity ( $34 \mathrm{~mJ} / \mathrm{cm}^{2}$ for a $3 \mathrm{D}$ reduction) is intermediate to the doses reported to be required to achieve similar reduction by $253.7-\mathrm{nm}$ radiation. However, additional studies applying both radiations (253.7 $\mathrm{nm}$ and 280 to $320 \mathrm{~nm}$ ) in similar doses to identical virus stocks are warranted.

Since the sensitivity of both animal caliciviruses to UV-B radiation was so much alike, we consider the effectiveness of UV radiation for the inactivation of caliciviruses to be intermediate, i.e., comparable to that for the enteroviruses (18), less effective than for vegetative bacteria, but more effective than for phage MS2 (11) and for adenovirus 2 (18), adenovirus 40 (40) and Bacillus subtilis spores (6).

The stability of $\mathrm{FeCV}$ in a wide $\mathrm{pH}$ range, i.e., less than complete inactivation for $3<\mathrm{pH}<9$, was clearly higher than the $\mathrm{pH}$-dependent stability of $\mathrm{CaCV}$. The low stability of $\mathrm{CaCV}$ at low $\mathrm{pH}$ was remarkable and suggests that this is not a typical enteric calicivirus, since it seems unlikely that $\mathrm{CaCV}$ will survive gastric passage. This might at least partly explain the lack of apparent clinical symptoms after experimental oral inoculation of dogs with $\mathrm{CaCV}$ no. 48 (38). With respect to the $\mathrm{pH}$ stability of the enteric noroviruses, it was shown that $3 \mathrm{~h}$ at $\mathrm{pH} 2.7$ (at room temperature) was not enough to completely inactivate Norwalk virus (12), suggesting that for the modeling of noroviruses in gastrointestinal conditions (i.e., low $\mathrm{pH}$ and high bile concentrations), other enteric viruses (e.g., poliovirus, hepatitis A virus, or rotavirus) might be better than the animal caliciviruses.

Overall, the two animal viruses showed similar high stabilities when incubated in $70 \%$ ethanol or hypochlorite solutions. The resistance of $\mathrm{FeCV}$ to chemical inactivation by ethanol and hypochlorite was shown by Doultree et al. (13) for short contact times. They extrapolated the 1-min contact time to recommend using hypochlorite solutions at $1,000 \mathrm{ppm}$ and a 10 min contact time. We found that at concentrations of up to 300 ppm, the effect of longer exposure times was insignificant for $\mathrm{FeCV}$ and only modest for $\mathrm{CaCV}$, indicating that extrapolation in time may be open to discussion. The incomplete inactivation by ethanol and the high chlorine concentrations needed for inactivation of both animal caliciviruses point to a concern for decontamination of fomites and surfaces contaminated with human noroviruses. The high chlorine resistance of the animal caliciviruses might indicate that the chlorine levels used in potable water treatment practices $(<20 \mathrm{ppm})$ do not cause a significant reduction of human norovirus infectivity.

A recognized problem with PCR detection of viral RNA is that the presence of RNA does not necessarily point to the presence of infectious virus $(17,36)$. We show that for most methods applied at levels where infectivity could no longer be detected, viral RNA remained detectable. Higher concentrations (chlorine), lower or higher $\mathrm{pH}$, or longer exposure times (heat and UV radiation) were needed to decrease the amount of detectable viral RNA than to abolish infectivity.

For most treatments, we found a good correlation between the decline of animal calicivirus RNA and the decline of norovirus RNA. This could indicate that the degree of protection of the RNAs by the viral capsids is comparable for all three viruses in the case of heat treatment, UV irradiation, or exposure to free chlorine. However, a remarkable difference in capsid stability was found after exposure to low $\mathrm{pH}$. The RNA of norovirus was still fully protected after exposure to $\mathrm{pH} 2$ for 30 min at $37^{\circ} \mathrm{C}$, while the amount of RNA of FeCV and $\mathrm{CaCV}$ was greatly reduced. This indicates that the truly enteric norovirus differs greatly from both animal caliciviruses with respect to acid stability, indicating again that $\mathrm{CaCV}$ is most likely not a true enteric pathogen.

Using the PCR protocols described, we found some discrepancies between the detectability of RNA by conventional PCR and by real-time PCR. For example, FeCV exposure to $\mathrm{pH} 2$ resulted in a less than $2 D$ reduction of real-time PCR-detectable RNA, while RNA detectable by the conventional PCR was reduced over $7 \mathrm{D}$. Similar but less dramatic effects were seen after boiling $\mathrm{FeCV}$ for $3 \mathrm{~min}$ and after $\mathrm{pH} 2$ and 3 treatment of $\mathrm{CaCV}$. We suspect that this may at least in part be explained by the much smaller size of the PCR products in the real-time PCR compared to the products of conventional PCR.

Although we showed that abolishment of infectivity was not always correlated to diminished detectability of the genome by PCR, we do believe that quantitative RT-PCR might be a 
valuable tool in detecting reduction in infectivity, because a delay in $C_{t}$ was always correlated to (some degree of) viral inactivation. Another PCR-based method to reduce positive RT-PCR results was based on treatment with proteinase $\mathrm{K}$ and RNase of UV-, hypochlorite-, or heat-exposed viruses prior to the reverse transcription step (33). A combination of both methods (i.e., proteinase $\mathrm{K}$ and RNase treatment and quantitative RT-PCR) may yield a more sensitive PCR-based method to detect viral inactivation.

On the basis of the data presented here on comparable inactivation rates for two animal caliciviruses ( $\mathrm{FeCV}$ and $\mathrm{CaCV}$ ) by a variety of methods, we postulate that the human enteric caliciviruses may display similar inactivation rates. In conclusion, we prefer the use of FeCV as model for the human enteric noroviruses over the use of $\mathrm{CaCV}$ due to the greater convenience of $\mathrm{FeCV}$ in the laboratory (i.e., higher titers after standard culture and easier recognition of cytopathic effect in titrations) and greater stability at low $\mathrm{pH}$. But even though the value of $\mathrm{FeCV}$ as a model for the noroviruses might be significant and preferable to the use of other virus families, extrapolation to a typical enteric virus might lead to over- or underestimation of the risk of infection, stressing again the need for an in vitro method for the detection of norovirus viability.

\section{ACKNOWLEDGMENTS}

This work was supported by the Netherlands Center Alternatives to Animal Use (PAD 97-31), the Netherlands Organization for Scientific Research (NWO 01412028), and the European Commission Quality of Life Program, 5th Framework (QLK1-CT-1999-00594).

We are grateful for the excellent assistance and feedback of Bas van der Veer, Erwin de Bruin, and Harry Vennema.

\section{REFERENCES}

1. Allwood, P. B., Y. S. Malik, C. W. Hedberg, and S. M. Goyal. 2003. Survival of F-specific RNA coliphage, feline calicivirus, and Escherichia coli in water: a comparative study. Appl. Environ. Microbiol. 69:5707-5710.

2. Bidawid, S., J. M. Farber, S. A. Sattar, and S. Hayward. 2000. Heat inactivation of hepatitis A virus in dairy foods. J. Food Prot. 63:522-528.

3. Boom, R., C. J. Sol, M. M. Salimans, C. L. Jansen, P. M. Wertheim-van Dillen, and J. van der Noordaa. 1990. Rapid and simple method for purification of nucleic acids. J. Clin. Microbiol. 28:495-503.

4. Brown, C. M., J. W. Cann, G. Simons, R. L. Fankhauser, W. Thomas, U. D. Parashar, and M. J. Lewis. 2001. Outbreak of Norwalk virus in a Caribbean island resort: application of molecular diagnostics to ascertain the vehicle of infection. Epidemiol. Infect. 126:425-432.

5. Carrique-Mas, J., Y. Andersson, B. Petersen, K. O. Hedlund, N. Sjogren, and J. Giesecke. 2003. A Norwalk-like virus waterborne community outbreak in a Swedish village during peak holiday season. Epidemiol. Infect. 131:737-744.

6. Chang, J. C., S. F. Ossoff, D. C. Lobe, M. H. Dorfman, C. M. Dumais, R. G. Qualls, and J. D. Johnson. 1985. UV inactivation of pathogenic and indicator microorganisms. Appl. Environ. Microbiol. 49:1361-1365.

7. Cheesbrough, J. S., J. Green, C. I. Gallimore, P. A. Wright, and D. W. Brown. 2000. Widespread environmental contamination with Norwalk-like viruses (NLV) detected in a prolonged hotel outbreak of gastroenteritis. Epidemiol Infect. 125:93-98.

8. Clarke, I. N., and P. R. Lambden. 2000. Organization and expression of calicivirus genes. J. Infect. Dis. 181(Suppl. 2):S309-S316.

9. Clarke, I. N., and P. R. Lambden. 1997. Viral zoonoses and food of animal origin: caliciviruses and human disease. Arch. Virol. Suppl. 13:141-152.

10. Couch, R. B. 2001. Rhinoviruses, p. 777-798. In D. M. Knipe, P. M. Howley, D. E. Griffin, R. A. Lamb, M. A. Martin, B. Roizman, and S. E. Straus (ed.), Fields virology, 4th ed. Lippincott Williams \& Wilkins, Philadelphia, Pa.

11. De Roda Husman, A. M., P. Bijkerk, W. Lodder, H. van den Berg, W. Pribil, A. Cabaj, P. Gehringer, R. Sommer, and E. Duizer. Calicivirus inactivation by nonionizing (UV-253.7 nm) and ionizing (gamma) radiation. Appl. Environ. Microbiol., in press.

12. Dolin, R., N. R. Blacklow, H. DuPont, R. F. Buscho, R. G. Wyatt, J. A. Kasel, R. Hornick, and R. M. Chanock. 1972. Biological properties of Norwalk agent of acute infectious nonbacterial gastroenteritis. Proc. Soc. Exp. Biol Med. 140:578-583.

13. Doultree, J. C., J. D. Druce, C. J. Birch, D. S. Bowden, and J. A. Marshall.
1999. Inactivation of feline calicivirus, a Norwalk virus surrogate. J. Hosp. Infect. 41:51-57.

14. Duizer, E., K. J. Schwab, F. H. Neill, R. L. Atmar, M. P. Koopmans, and M. K. Estes. 2004. Laboratory efforts to cultivate noroviruses. J. Gen. Virol. 85:79-87.

15. Evans, M. R., R. Meldrum, W. Lane, D. Gardner, C. D. Ribeiro, C. I. Gallimore, and D. Westmoreland. 2002. An outbreak of viral gastroenteritis following environmental contamination at a concert hall. Epidemiol. Infect. 129:355-360.

16. Fankhauser, R. L., S. S. Monroe, J. S. Noel, C. D. Humphrey, J. S. Bresee, U. D. Parashar, T. Ando, and R. I. Glass. 2002. Epidemiologic and molecular trends of "Norwalk-like viruses" associated with outbreaks of gastroenteritis in the United States. J. Infect. Dis. 186:1-7.

17. Gassilloud, B., L. Schwartzbrod, and C. Gantzer. 2003. Presence of viral genomes in mineral water: a sufficient condition to assume infectious risk? Appl. Environ. Microbiol. 69:3965-3969.

18. Gerba, C. P., D. M. Gramos, and N. Nwachuku. 2002. Comparative inactivation of enteroviruses and adenovirus 2 by UV light. Appl. Environ. Microbiol. 68:5167-5169.

19. Green, K. Y. 1997. The role of human caliciviruses in epidemic gastroenteritis. Arch. Virol. Suppl. 13:153-165.

20. Hashimoto, M., F. Roerink, Y. Tohya, and M. Mochizuki. 1999. Genetic analysis of the RNA polymerase gene of caliciviruses from dogs and cats. J. Vet. Med. Sci. 61:603-608

21. Helps, C., and D. Harbour. 2003. Detection of nucleotide polymorphisms in feline calicivirus isolates by reverse transcription PCR and a fluorescence resonance energy transfer probe. J. Virol. Methods 109:261-263.

22. Kadoi, K., and B. K. Kadoi. 2001. Stability of feline caliciviruses in marine water maintained at different temperatures. New Microbiol. 24:17-21.

23. Koopmans, M., and E. Duizer. 2004. Foodborne viruses: an emerging problem. Int. J. Food Microbiol. 90:23-41.

24. Kukkula, M., L. Maunula, E. Silvennoinen, and C. H. von Bonsdorff. 1999. Outbreak of viral gastroenteritis due to drinking water contaminated by Norwalk-like viruses. J. Infect. Dis. 180:1771-1776.

25. Kuusi, M., J. P. Nuorti, L. Maunula, N. N. Minh, M. Ratia, J. Karlsson, and C. H. von Bonsdorff. 2002. A prolonged outbreak of Norwalk-like calicivirus (NLV) gastroenteritis in a rehabilitation centre due to environmental contamination. Epidemiol. Infect. 129:133-138.

26. Lee, K. M., and J. H. Gillespie. 1973. Thermal and $\mathrm{pH}$ stability of feline calicivirus. Infect. Immun. 7:678-679.

27. Lopman, B. A., D. W. Brown, and M. Koopmans. 2002. Human caliciviruses in Europe. J. Clin. Virol. 24:137-160.

28. Lopman, B. A., M. H. Reacher, Y. Van Duijnhoven, F. X. Hanon, D. Brown, and M. Koopmans. 2003. Viral gastroenteritis outbreaks in Europe, 19952000. Emerg. Infect. Dis. 9:90-96.

29. Millard, J., H. Appleton, and J. V. Parry. 1987. Studies on heat inactivation of hepatitis A virus with special reference to shellfish. 1. Procedures for infection and recovery of virus from laboratory-maintained cockles. Epidemiol. Infect. 98:397-414.

30. Mochizuki, M. 1992. Different stabilities to bile among feline calicivirus strains of respiratory and enteric origin. Vet. Microbiol. 31:297-302.

31. Mochizuki, M., M. Hashimoto, F. Roerink, Y. Tohya, Y. Matsuura, and N. Sasaki. 2002. Molecular and seroepidemiological evidence of canine calicivirus infections in Japan. J. Clin. Microbiol. 40:2629-2631.

32. Mochizuki, M., A. Kawanishi, H. Sakamoto, S. Tashiro, R. Fujimoto, and M. Ohwaki. 1993. A calicivirus isolated from a dog with fatal diarrhoea. Vet. Rec. 132:221-222.

33. Nuanualsuwan, S., and D. O. Cliver. 2002. Pretreatment to avoid positive RT-PCR results with inactivated viruses. J. Virol. Methods 104:217-225.

34. Nuanualsuwan, S., T. Mariam, S. Himathongkham, and D. O. Cliver. 2002. Ultraviolet inactivation of feline calicivirus, human enteric viruses and coliphages. Photochem. Photobiol. 76:406-410.

35. Parshionikar, S. U., S. Willian-True, G. S. Fout, D. E. Robbins, S. A. Seys, J. D. Cassady, and R. Harris. 2003. Waterborne outbreak of gastroenteritis associated with a norovirus. Appl. Environ. Microbiol. 69:5263-5268.

36. Richards, G. P. 1999. Limitations of molecular biological techniques for assessing the virological safety of foods. J. Food Prot. 62:691-697.

37. Rockx, B., M. De Wit, H. Vennema, J. Vinje, E. De Bruin, Y. Van Duynhoven, and M. Koopmans. 2002. Natural history of human calicivirus infection: a prospective cohort study. Clin. Infect. Dis. 35:246-253.

38. San Gabriel, M. C., Y. Tohya, T. Sugimura, T. Shimizu, S. Ishiguro, and M. Mochizuki. 1997. Identification of canine calicivirus capsid protein and its immunoreactivity in western blotting. J. Vet. Med. Sci. 59:97-101.

39. Slomka, M. J., and H. Appleton. 1998. Feline calicivirus as a model system for heat inactivation studies of small round structured viruses in shellfish. Epidemiol. Infect. 121:401-407.

40. Thurston-Enriquez, J. A., C. N. Haas, J. Jacangelo, K. Riley, and C. P. Gerba. 2003. Inactivation of feline calicivirus and adenovirus type 40 by UV radiation. Appl. Environ. Microbiol. 69:577-582.

41. Vennema, H., E. de Bruin, and M. Koopmans. 2002. Rational optimization of generic primers used for Norwalk-like virus detection by reverse transcriptase polymerase chain reaction. J. Clin. Virol. 25:233-235. 